\title{
PENGARUH PENERAPAN METODE JARIMATIKA TERHADAP KEMAMPUAN BERHITUNG BILANGAN BULAT POSITIF PADA SISWA KELAS IVA MIN MALAWELE
}

Muhammad Akram G ${ }^{1}$, Syamsul Alam Ramli ${ }^{2}$

${ }^{1}$ SDIT Al-Izzah Sorong, ${ }^{2}$ Universitas Muhammadiyah Palopo

${ }^{1}$ Email: akrampelmaha25@gmail.com

${ }^{I}$ Orcid Id: https://orcid.org/0000-0003-0393-5947

\author{
Article received : 2020-11-28 \\ Review process : 2020-12-21 \\ Article published : 2020-12-23
}

\begin{abstract}
This research is motivated by the students' low numeracy skills. Based on the results of observations by researchers in class IVA during the implementation of PPL in the 2017/2018 academic year, from 21 students, there were 14 students who were not proficient in arithmetic (66\%) and those who were proficient but still needed guidance, there were 7 students (34\%). In this case, the researcher tried an experimental study in mathematics learning, especially positive integer material using the Jarimatika method. Based on the descriptive statistical calculation of the average pretest and posttest mean with a total of 21 students, the pretest average obtained a minimum value of 23.75, a maximum value of 96.25, an average value of 66.07, and a standard deviation of 18.688, while the average postest obtained a minimum value of 61.25, a maximum value of 97.50, an average value of 81.72 and a standard deviation value of 10.922. This study was declared successful by looking at the difference in the average pretest and postest results from 66.07 to 81.72. This shows that there is an effect of the Jarimatika method on the counting ability of positive integers in class IVA MIN Malawele, Sorong Regency.
\end{abstract}

Keywords: Learning outcomes, numeracy skills, Jarimatika method.

\begin{abstract}
Abstrak
Penelitian ini dilatarbelakangi oleh kemampuan berhitung siswa yang masih rendah. Berdasarkan hasil observasi peneliti di kelas IVA pada saat pelaksanaan PPL tahun akademik 2017/2018, dari 21 siswa, terdapat 14 siswa yang belum mahir berhitung (66\%) dan yang mahir namun masih perlu dibimbing terdapat 7 siswa (34\%). Dalam hal ini peneliti mencoba suatu penelitian eksperimen dalam pembelajaran matematika khususnya materi bilangan bulat positif dengan menggunakan metode jarimatika. Berdasarkan perhitungan statisktik deskriptif rata-rata pretest dan rata-rata postest dengan jumlah 21 siswa maka: rata-rata pretest diperoleh nilai minimum 23,75, nilai maksimum 96,25 , nilai rata-rata 66,07, dan nilai simpangan baku 18,688, sedangkan rata-rata postest diperoleh nilai minimum 61,25, nilai maksimum 97,50, nilai rata-rata 81,72 dan nilai simpangan baku 10,922. Penelitian ini dinyatakan berhasil dengan melihat perbedaan hasil rata-rata pretest dengan postest dari 66,07 menjadi 81,72. Hal ini menunjukkan bahwa adanya pengaruh metode jarimatika terhadap kemampuan berhitung bilangan bulat positif siswa kelas IVA MIN Malawele Kabupaten Sorong.
\end{abstract}

Kata Kunci: Hasil belajar, Kemampuan berhitung, Metodejarimatika. 


\section{Pendahuluan}

Keterampilan dasar yang harus dimiliki oleh siswa Sekolah Dasar maupun Madrasah Ibtidaiyah meliputi tiga standar kemampuan yaitu membaca, menulis, dan berhitung (calistung). Kemampuan membaca adalah kemampuan memahami, melisankan, melafalkan atau mengucapkan apa yang tertulis. Kemampuan menulis adalah kemampuan mengungkapkan gagasan dan perasaan seseorang yang diungkapkan dalam bahasa tulis, (Abbas, 2006:125). Sedangkan kemampuan berhitung adalah kemampuan seseorang yang digunakan untuk menyelesaikan masalah matematika dengan operasi perhitungan atau aritmatika biasa.

Kemampuan berhitung merupakan landasan dasar dalam pelajaran matematika. Berhitung berhubungan dengan sistem bilangan. Sebuah sistem bilangan diorganisasikan dengan cara merepresentasikan kembali bilangan-bilangan dengan berbagai kombinasi sistem simbol, (Runtukahu dan Kandou, 2016:83). Salah satunya adalah bilangan bulat. Bilangan bulat terdiri dari bilangan positif, bilangan 0, dan bilangan negatif. Bilangan bulat merupakan pengetahuan dasar untuk semua kegiatan berhitung. Maka penanaman konsep berhitung wajib diajarkan sejak usia dini. Retno Rianti, bilangan adalah sebuah ide yang digunakan untuk menunjukkan suatu jumlah. Bilangan memiliki sifat abstrak, (Retno Rianti, 2010:1). Menurut Reys dkk mengemukakan bahwa dalam mengadakan operasi bilangan dibutuhkan prasyarat tertentu. Tiga syarat utama operasi bilangan yaitu Keterampilan membilang, Pengalaman konkret, Kemampuan bahasa, (Runtukahu dan Kandou, 2016:102).

Namun pada kenyataannya kemampuan berhitung siswa sekolah dasar tidak begitu dikuasai oleh siswa sehingga prestasi belajar matematika kurang maksimal. Ini mungkin disebabkan karena proses pembelajaran yang monoton, berupa ceramah, hafalan dan hanya terpusat pada guru sehingga siswa merasa bosan dan kesulitan dalam belajar berhitung. Berdasarkan hasil observasi di kelas IVA pada saat pelaksanaan PPL dari 21 siswa, terdapat 14 siswa yang belum mahir berhitung $(66 \%)$ dan yang mahir namun masih perlu dibimbing terdapat 7 siswa (34\%). Berdasarkan temuan masalah di atas, maka akan dilakukan suatu penelitian lebih lanjut dengan mencoba menerapkan suatu metode yang disebut metode jarimatika.

Jarimatika adalah salah satu cara berhitung dengan menggunakan alat bantu jari tangan, melalui pembelajaran jarimatika siswa tidak perlu membeli alat peraga karena pembelajaran seperti ini sangat praktis dengan menggunakan jari-jari tangan sebagai alat berhitung. Dengan pembelajaran jarimatika ini siswa dilatih untuk menghapal perkalian dasar. Keterlibatan siswa untuk memperagakan jarimatika dapat membuat pelajaran semakin bermakna. Siswa dapat menggunakan jari tangannya untuk menyelesaikan berhitung berdasarkan aturan formasi tangan dan penyelesaian jarimatika.

Pembelajaran jarimatika ini selain fleksibel juga tidak memberatkan memori otak kanan anak dalam proses berhitung dan anak-anak akan berhitung dengan mudah dan menyenangkan. Tidak perlu bawa kalkulator saat ulangan cukup dengan jari tangan kita sendiri, sehingga pembelajaran matematika akan lebih berkesan dan menarik sehingga membangkitkan minat belajar siswa, (Erna Mayasari, 2002:2). Jarimatika memperkenalkan kepada anak bahwa matematika khusunya berhitung itu menyenangkan. Jarimatika suatu metode yang dapat digunakan dalam pembelajaran khususnya dalam berhitung, sedangkan media yang digunakan adalah jari-jari tangan dan pengoprasian jarimatika terdapat aturanaturan tertentu, (Agung Prasetyo Nugroho, 2014:13).

Hal ini berarti bahwa metode jarimatika sangat memegang peranan penting dalam upaya meningkatkan kemampuan berhitung siswa dalam pembelajaran matematika. 
Beberapa penelitian menunjukkan bahwa metode ini dinilai lebih memudahkan siswa menyelesaikan permasalahan matematika yang dapat membuat pembelajaran jadi menyenangkan. Sebagaimana dalam penelitian Husnul Khatimah, Pembelajaran Berhitung Dengan Menggunakan Jarimatika Untuk Meningkatkan Motivasi Belajar Dan Kemampuan Berhitung Siswa DI MIN Candirejo Ngawen Tahun 2012. Masalah penelitian ini tentang penerapan metode jarimatika berpengaruh terhadap kemampuan berhitung bilangan bulat positif siswa kelas IVA MIN Malewele. Bertujuan untuk mengetahui pengaruh penerapan metode jarimatika terhadap kemampuan berhitung bilangan bulat positif pada siswa kelas IVA MIN Malawele.

\section{Metode}

Jenis penelitian ini adalah penelitian eksperimen dengan pendekatan kuantitatif. Penelitian Eksperimen yaitu metode penelitian yang digunakan untuk mengetahui pengaruh dari suatu tindakan atau perlakuan tertentu (treatment) yang sengaja dilakukan terhadap suatu kondisi tertentu, (Wina Sanjaya, 2013:250). Sedangkan pendekatan kuantitatif dapat diartikan sebagai pendekatan yang berdasarkan pada filsafat positivisme, digunakan untuk meneliti pada populasi atau sampel tertentu, teknik pengambilan sampel pada umumnya dilakukan secara random, pengumpulan data menggunakan instrumen penelitian, analisis data bersifat kuantitatif/statistik dengan tujuan untuk menguji hipotesis yang telah ditetapkan. (Sugiyono, 2015:14).

Desain penelitian dalam melaksanakan penelitian ini adalah eksperimen semu (Quasi Experimental Design). Desain penelitian ini hanya menggunakan satu kelompok saja, sehingga tidak memerlukan kelompok kontrol. Adapun desain eksperimen dapat digambarkan sebagai berikut:

\section{$\begin{array}{lllllllll}\mathbf{Q}_{1} & \mathbf{Q}_{2} & \mathbf{Q}_{3} & \mathbf{Q}_{4} & \mathbf{X} & \mathbf{Q}_{5} & \mathbf{Q}_{6} & \mathbf{Q}_{7} & \mathbf{Q}_{8}\end{array}$}

\section{Gambar 1: Penelitian Time series Design}

Keterangan:

$\mathrm{Q}_{1} \quad=$ Hasil Pretest kelompok eksperimen tahap 1

$\mathrm{Q}_{2} \quad=$ Hasil Pretest kelompok eksperimen tahap 2

Q3 $=$ Hasil Pretest kelompok eksperimen tahap 3

$\mathrm{Q}_{4} \quad=$ Hasil Pretest kelompok eksperimen tahap 4

Q5 $\quad=$ Hasil Postest kelompok eksperimen tahap 1

Q6 $\quad=$ Hasil Postest kelompok eksperimen tahap 2

$\mathrm{Q}_{7} \quad=$ Hasil Postest kelompok eksperimen tahap 3

Q8 $\quad=$ Hasil Posttest kelompok eksperimen tahap 4

$\mathrm{X} \quad=$ Treatment (Perlakuan) berupa metode jarimatika

Prosedur penelitian adalah langkah-langkah atau tahapan yang akan dilakukan dalam suatu penelitian sehingga penelitian bersifat sistematis. Dalam penelitian ini, adapun langkah-langkah penelitian eksperimen adalah sebagai berikut:

\section{Tahap pra eksperimen}

Tahap ini digunakan untuk mempersiapkan segala sesuatu yang diperlukan dalam eksperimen yaitu menentukan pokok bahasan yang sesuai untuk penelitian, merancang media pembelajaran, mencocokan pokok bahasan dengan media pembelajaran, melakukan penentuan sekolah tempat penelitian, membuat surat perijinan penelitian kepada pihak-pihak sekolah, pembuatan rencana pelaksanaan pembelajaran, pembuatan instrument dan pengujian instrument, penentuan kelas eksperimen. 


\section{Tahap eksperimen}

Pada tahap ini terdiri atas pretest, treatment atau perlakuan dan postest. Adapun penjelasannya yaitu (a) Pretest adalah tes awal yang dilakukan untuk mengetahui seberapa besar pemahaman awal siswa dalam pelajaran pokok bahasan bilangan bulat yang kemudian akan dibandingkan dengan hasil belajar yang dicapai siswa setelah diberi perlakuan. Pretest diberikan kepada siswa sebelum perlakuan baik di kelas eksperimen; (b) Treatment atau Perlakuan, Pada tahap ini guru memberikan treatment atau perlakuan pada kelas eksperimen. Perlakuan yang dimaksud adalah penerapan metode jarimatika dalam pembelajaran operasi hitung bilangan bulat positif; (3) Postest dilakukan untuk melihat pencapaian peningkatan hasil belajar setelah diberi perlakuan. Hasil belajar ini akan dibandingkan dengan nilai atau hasil belajar siswa yang dicapai saat pretest, apakah hasil belajar yang dicapai sama, meningkat atau justru menurun.

\section{Tahap pasca eksperimen}

Setelah pretest dan postest diberikan, selanjutnya dilakukan tahap pasca eksperimen. Tahap ini merupakan tahap penyelesaian dari penelitian ini. Dalam tahap ini data pretest dan postest dianalisis meggunakan perhitungan secara statistik. Hasil perhitungan tersebut digunakan untuk menjawab hipotesis apakah diterima atau tidak. Populasi atau universe, adalah jumlah keseluruhan dari unit analisa yang ciri-cirinya akan diduga, (Suharsimi Arikunto, 1998:117). Populasi dalam penelitian ini adalah semua siswa kelas IVA yang berjumlah 21 siswa. Menurut Arikunto, sampel adalah "sebagian individu atau wakil populasi yang diteliti, (Suharsimi Arikunto, 1998:117). Lebih lanjut Arikunto menjelaskan bahwa: "sebagian acuan apabila subyek yang diteliti kurang dari 100, lebih baik diambil semua sehingga penelitiannya merupakan penelitian populasi, sedangkan jika lebih dari 100, maka lebih baik diambil antara 10\%, 15\%, atau 25\% atau lebih". Atas dasar pemikiran tersebut dan realita populasi berjumlah kurang 100 orang, maka sampel yang dijadikan responden dalam penelitian ini adalah sampel total (seluruh populasi).

Penelitian ini dilaksanakan di Madrasah Ibtidaiyah Negeri (MIN) Malawele Aimas Kabupaten Sorong Provinsi Papua Barat. Waktu pelaksanaan penelitian dimulai pada pertengahan bulan April 2018 sampai pertengahan bulan Mei 2018. Adapun yang menjadi subjek penelitian dalam penelitian ini adalah siswa di kelas IVA MIN Malawele Aimas Kabupaten Sorong tahun ajaran 2017/2018 yang jumlahnya 21 siswa. Penarikan sampel dilakukan karena sekolah tersebut salah satu SD/MI terbaik di Kabupaten Sorong.

Penelitian di kelas IVA ini didasarkan atas pertimbangan bahwa siswa telah memiliki pra syarat yang cukup untuk materi yang menjadi objek penelitian ini, yang mana dalam Laporan PPL STAIN Sorong tahun akademik 2017/2108 dikemukakan kemampuan berhitung siswa sebagian besar belum mencapai KKM, khususnya dalam materi perkalian bilangan bulat positif. Berdasarkan hal tersebut maka peneliti melakukan penelitian di kelas tersebut dengan memberikan metode terbaru yang belum pernah diajarkan sebelumnya yaitu metode jarimatika untuk melihat pengaruh terhadap kemampuan berhitung siswa.

Instrumen penelitian merupakan alat bantu bagi peneliti mengumpulkan data yang dibutuhkan dalam penelitian. Kualitas instrumen akan menentukan kualitas data yang terkumpul, (Suharsimi Arikunto, 2010:134). Instrumen juga digunakan sebagai alat yang digunakan untuk mengukur variabel yang diteliti. Dalam kegiatan penelitian untuk memperoleh data yang berasal dari lapangan, seorang peneliti biasanya menggunakan instrumen yang baik dan mampu mengambil informasi dari subjek atau objek yang diteliti.

Dalam bidang pendidikan ada tingkah laku instrumen penelitian pada umumnya perlu mempunyai dua syarat penting, yaitu valid dan reliabel, (Sukardi, 2003:121). Pada tahap 
validitas dan reabulitas inilah tes hasil kreativitas diuji kualitasnya sebagai suatu perangkat seacara menyeluruh. Pengujiannya dilakukan setelah pengujian atas kualitas pada masingmasing butir.

Jenis instrumen yang digunakan dalam penelitian ini adalah: Instrumen tes adalah alat untuk mengumpulkan data tentang kemampuan subyek penelitian dengan cara mengukur kemampuan subyek, baik kemampuan dalam bidang kognitif, afektif, Maupun psikomotorik, (Wina Sanjaya, 2013:251). Instrumen tes diberikan sebelum perlakuan (pretest) dan setelah perlakuan (postest) yang bertujuan untuk mengukur ada dan tidaknya peningkatan hasil belajar siswa dan seberapa besar pengaruh metode jarimatika dalam menentukan hasil pembelajaran di kelas IV. Soal diberikan secara tertulis dalam bentuk uraian karena berkaitan dengan hasil belajar. Selain itu dipilih soal bentuk uraian untuk menhindari unsur tebakan.

Tes kemampuan pemecahan masalah ini disusun oleh penulis dengan langkah-langkah pengembangan yaitu (a) menyusun kisi-kisi yang memuat dan sesuai dengan bahan ajar pemecahan masalah, standar kompetensi, dan indikator; (b) menyusun soal tes berdasarkan kisi-kisi serta membuat kunci jawabannya dan rubrik penskoran disajikan secara lengkap pada lampiran; (c) menilai validasi isi soal dan kebenaran kunci jawaban oleh dosen pembimbing, rekan mahasiswa PGMI dan guru Madrasah Ibtidaiyah; (d) mempertimbangkan keterbacaan soal, apakah soal tersebut dapat dipahami atau tidak yang dilakukan oleh dosen pembimbing, mahasiswa PGMI dan guru Madrasah Ibtidaiyah.

Dokumentasi berasal dari kata doku men yang artinya barang-barang tertulis. Dalam melaksanakan teknik dokumentasi, peneliti menyelidiki benda-benda tertulis seperti bukubuku, dokumen, peraturan-peraturan, notulen rapat, catatan harian, dan sebagainya, (Suharsimi Arikunto, 2010:231). Dokumentasi merupakan teknik pengumpulan data, pengolahan, penyimpanan data yang digunakan sebagai bukti atau keterangan. Dokumentasi yang dimaksud dalam penelitian ini berupa daftar nilai siswa atau nilai hasil belajar sebelum dan sesudah penerapan metode jarimatika, dan juga foto/gambar yang diambil selama kegiatan pembelajaran dikelas dalam praktik penerapan metode jarimatika.

Untuk memperoleh data yang diharapkan maka dalam suatu penelitian diperlukan teknik pengumpulan data. Langkah ini sangat penting karena data yang dikumpulkan nanti akan digunakan dalam menguji hipotesis. Dalam melakukan teknik pengumpulan data harus disesuaikan dengan data yang diperlukan.

Pada penelitian ini, teknik pengumpulan data yang digunakan adalah: Teknik dokumentasi, teknik ini merupakan setiap pernyataan, pengambilan gambar atau video dari kegiatan penelitian sebagai bukti fisik untuk mendukung keaslian penelitian. Teknik tes, tes merupakan alat atau prosedur yang digunakan untuk mengetahui atau mengukur sesuatu dalam suasana, dengan cara dan atau aturan-aturan yang sudah ditentukan, (Suharsimi Arikunto, 2010:53).

Bentuk Instrumen tes, bentuk instrument pada penelitian ini adalah lembar soal tes berupa pertanyaan yang berkaitan dengan penguasaan pokok bahasan yang disampaikan. Banyak soal yang diberikan adalah 20 soal dengan bentuk soal pilihan ganda, Skor nilai 10 untuk 1 jawaban benar. Tes tertulis dilakukan untuk mengetahui penguasaan siswa terhadap pokok bahasan yang disampaikan. Uji Coba Instrumen, data mempunyai kedudukan yang paling tinggi karena data merupakan penggambaran variabel yang diteliti dan berfungsi sebagai alat pembuktian hipotesis dalam penelitian. Menurut Husen benar tidaknya suatu data sangat menentukan bermutu tidaknya hasil penelitian. Sedangkan benar tidaknya data tergantung dari baik tidaknya instrument pengumpulan data, (Syarifuddin Yunus Kadang, 2015:28). Instrumen yang baik setidaknya memenuhi 2 kriteria yaitu, validitas dan reliabilitas. Validitas adalah sejauh mana data yang ditampung pada soal tes akan mengukur yang ingin 
diukur, reliabilitas merupakan sejauh mana suatu hasil pengukuran relatif konsisten apabila alat ukur digunakan berulang kali. Validitas adalah menunjukkan sejauh mana suatu alat ukur mampu mengukur apa yang ingin diukur, (Syofian Siregar, 46). Jadi validitas adalah tingkat kevalidan atau keshahihan suatu alat ukur. Uji validitas instrument penelitian ini sangat penting dilakukan untuk mengetahui tingkat keabsahan instrumen yang digunakan dengan objek yang akan diukur. Dalam penelitian ini jenis validitas yang akan digunakan adalah validitas isi dan validitas konstruk. Validitas isi (Content Validity) adalah kemampuan suatu instrument mengukur isi atau konsep yang hendak diukur. Hal ini berarti validitas pada soal melalui validitas isi berupa soal yang akan diujikan dan dikonsultasikan oleh guru dan pembimbing. Setelah para ahli menyatakan instrumet telah valid maka instrumen penelitian dapat diujikan kepada subjek penelitian. Reliabel berarti tetap atau stabil. Menurut Arikunto reliabilitas adalah menunjukkan suatu pengertian bahwa suatu instrumen sudah cukup dapat dipercaya atau digunakan sebagai alat karena instrumen tersebut sudah baik. Reliabilitas adalah untuk mengetahui sejauh mana hasil pengukuran tetap konsisten apabila dilakukan pengukuran dua kali atau lebih terhadap gejala yang sama dengan menggunakan alat pengukur yang sama pula, (Syofian Siregar, 55).

Dalam penelitian kuantitatif, analisis data merupakan kegiatan setelah data dari seluruh responden atau sumber data lain terkumpul. Analisis data adalah pengelompokan data berdasarkan jenis variabel dan responden, mentabulasi data berdasarkan variabel dari seluruh responden, menyajikan data tiap variabel yang diteliti, melakukan perhitungan untuk menjawab rumusan masalah dan menguji hipotesis yang telah diajukan. Secara singkat kegiatan dalam analisis data yaitu (a) Pengolahan data dan penyajian data; (b) melakukan perhitungan untuk mendeskripsikan data; (c) Melakukan pengujian hipotesis dengan menggunakan uji statistik. Dalam penelitian ini data diperoleh secara langsung dengan metode eksperimen untuk mengetahui peningkatan hasil belajar siswa atau tingkat pemahaman siswa. Adapun tujuan dari analisis data dalam penelitian ini adalah untuk mengetahui pengaruh metode jarimatika terhadap kemampuan berhitung bilangan bulat positif pada siswa kelas IVA MIN Malawele dalam pembelajaran matematika.

Adapun teknik pengumpulan data yang akan dianalisa adalah data yang diperoleh dari masing-masing variabel ditabulasikan dengan menggunakan table distribusi frekuensi. Dari tabulasi kemudian dicari harga simpangan baku, mean, modus, median, nilai terendah, nilai tertinggi, dan setiap data dihitung dengan SPSS. 22. Uji Normalitas adalah sebuah uji yang dilakukan dengan tujuan untuk menilai sebaran data pada sebuah kelompok data atau variabel, apakah sebaran data tersebut berdistribusi normal ataukah tidak. Uji normalitas ini merupakan salah satu syarat mutlak untuk melakukan analisis statistik parametrik. Jadi uji normalitas ini berfungsi untuk mengetahui apakah data yang diperoleh dapat digunakan untuk tahap selanjutnya. Uji normalitas ini menggunakan uji Kolmogorov-Smirnov dan uji Shapiro-Wilk dengan bantuan soft ware SPSS. 22. Adapun pengambilan keputusan dalam uji Kolmogorov-Smirnov dan Uji Shapiro Wilk adalah jika nilai signifikan kedua uji ini lebih besar daripada nilai probabilitas statistik parametrik sebesar 0,050. Apabila semua data terdistribusi normal maka dapat dilakuakan analisis data menggunakan uji statistik parametrik. Namun apabila data tidak terdistribusi normal maka dapat dilakukan uji statistik non parametrik.

Pengujian hipotesis dimaksudkan untuk menguji apakah diterima atau tidaknya hipotesis yang telah diajukan. Uji hipotesis penelitian ini didasarkan pada perbedaan hasil belajar, yaitu data selisih pretes dan postes. Pengujian hipotesis pada penelitian ini harus lebih dahulu mengetahui perbedaan nilai objek penelitian sebelum dan sesudah diberikan perlakuan. Dalam penelitian ini analisis data menggunakan metode analisis data regresi. Analisis regresi merupakan salah satu analisis yang bertujuan untuk mengetahui pengaruh 
suatu variabel terhadap variabel lain. Dalam analisis regresi, variabel yang mempengaruhi disebut Independent Variabel (variabel bebas X) dan variabel yang dipengaruhi disebut Dependent Variabel (variabel terikat Y). Jika dalam persamaan regresi hanya terdapat satu variabel bebas dan satu variabel terikat, maka disebut sebagai persamaan regresi sederhana. Analisis Regresi Sederhana digunakan untuk mengetahui pengaruh dari variabel bebas terhadap variabel terikat atau dengan kata lain untuk mengetahui seberapa jauh perubahan variabel bebas dalam mempengaruhi variabel terikat.

\section{Hasil dan Pembahasan}

Subyek penelitian dalam penelitian ini adalah siswa kelas IVA MIN Malawele Aimas Kabupaten Sorong sebagai kelas eksperimen dengan bentuk time series design dalam pembelajaran matematika dengan metode jarimatika. Data hasil penelitian ini terbagi menjadi dua bagian, yaitu data sebelum diberi perlakuan (Pretest) dan data setelah diberikan perlakuan (Postest). Berdasarkan perhitungan statisktik deskriptif pretest 1-4 dengan jumlah 21 siswa maka: pretest 1 diperoleh nilai minimum 30, nilai maksimum 95, nilai rata-rata 73,33, dan nilai simpangan baku 20,145, Pretest 2 diperoleh nilai minimum 5, nilai maksimum 100, nilai rata-rata 73,80, dan nilai simpangan baku 25,441, Pretest 3 diperoleh nilai minimum 10 , nilai maksimum 95 , nilai rata-rata 69,28 , dan nilai simpangan baku 22,152, Pretest 4 diperoleh nilai minimum 15, nilai maksimum 95, nilai rata-rata 47,85, dan nilai simpangan baku 24,676.

Berdasarkan perhitungan statisktik deskriptif postest 1-4 dengan jumlah 21 siswa maka: postest 1 diperoleh nilai minimum 60, nilai maksimum 100 , nilai rata-rata 84,76 dan nilai simpangan baku 12, Postest 2 diperoleh nilai minimum 55, nilai maksimum 100, nilai rata-rata 83,57 dan nilai simpangan baku 12,761, Pretest 3 diperoleh nilai minimum 60, nilai maksimum 100, nilai rata-rata 84,52 dan nilai simpangan baku 13,313 dan Pretest 4 diperoleh nilai minimum 60 , nilai maksimum 95 , nilai rata-rata 74,04 dan nilai simpangan baku 11,137.

Berdasarkan perhitungan statisktik deskriptif rata-rata pretest dan rata-rata postest dengan jumlah 21 siswa maka: rata-rata pretest diperoleh nilai minimum 23,75, nilai maksimum 96,25, nilai rata-rata 66,07, dan nilai simpangan baku 18,688, sedangkan ratarata postest diperoleh nilai minimum 61,25 , nilai maksimum 97,50, nilai rata-rata 81,72 dan nilai simpangan baku 10,922.

Uji prasyarat analisis dilakukan untuk mengetahui apakah penelitian yang dilaksanakan dapat dilanjutkan atau tidak. Beberapa teknik analisis data memungkinkan agar sebuah data berdistribusi normal sesuai dengan uji analisis yang telah ada. Dalam penelitian ini analisis prasyarat datanya harus berdistribusi normal. Peneliti menggunakan uji prasyarat analisis yakni terdiri dari uji normalitas dan uji one sample $t$ test. Berikut beberapa penjelasan tentang uji prasyarat yang terdapat dalam penelitian ini yaitu uji normalitas digunakan untuk mengetahui apakah data yang diteliti dapat berdistribusi normal atau tidak. Apabila signifikansinya $>0,05$ maka data tersebut dapat dikatakan berdistribusi normal. Untuk mengetahui bagaimana suatu data dapat berdistribusi normal atau tidak, peneliti menggunakan aplikasi soft ware SPSS 22.

Dari hasil penelitian data yang dilakukan dengan dua uji sekaligus yaitu uji Kolmogorov-Smirnov dan uji Shapiro-Wilk maka uji normalitas diperoleh nilai signifikan pada data pretest sebesar 0,200 dengan uji kolmogorov dan 0,782 melalui uji Shapiro Wilk. Sedangkan uji normalitas data postest diperoleh nilai signifikansi 0,200 melalui uji kolmogorov dan 0,267 melalui uji Shapiro-wilk. Berdasarkan kriteria pada uji normalitas bahwa jika sig $>5 \%$ atau 0,05 maka hipotesis diterima. Jadi, data nilai pretest dan posttest pada kelas IVA MIN Malawele dinyatakan berdistribusi normal. Uji ini digunakan untuk 
satu sampel data. Hasil dari sampel ini dibandingkan dengan suatu nilai konstan agar diketahui adanya perbedaan atau tidak. Syarat uji ini yaitu data harus kuantitatif dan berdistribusi normal. Dari data yang telah diperoleh saat uji normalitas selanjutnya dapat di uji perbedaannya melalui uji one sample t test dengan perolehan hasil bahwa jumlah siswa sebanyak 21 orang dengan nilai rata-rata yang diperoleh dari postest sebesar 81,73 sedangkan simpangan baku 10,922 dan standar error 2,383. Dari data hasil rata-rata postest diperolehan t hitung sebesar 6,598 dengan df sebesar 20 sehingga menghasilkan nilai sig. (2 tailed) yakni 0,00. Adapun perbandingan antara nilai sig. (2 tailed) $<0,05$ maka dapat disimpulkan bahwa $\mathrm{H}_{0}$ ditolak dan diterima hipotesis alternatifnya $\left(\mathrm{H}_{1}\right)$ yaitu adanya pengaruh metode jarimatika terhadap kemampuan berhitung pada kelas IVA MIN Malawele Aimas Kabupaten Sorong. Sehingga diketahui bahwa terdapat perbedaan antara sebelum diberi perlakuan dengan sesudah diterapkannya metode jarimatika dengan hasil analisis data diperoleh signifikansi $0,00<0,05$ yang dinyatakan dalam pengolahan statistik bahwa peneliti bisa dikatakan berhasil dalam penelitiannya.

\section{Pengaruh metode jarimatika sebelum dan sesudah diberikan perlakuan}

Berdasarkan data nilai pada saat pretest dan postest yang dilaksanakan pada bulan April sampai Mei 2018 di MIN Malawele Aimas telah dijelaskan pada uji normalitas yang menunjukkan bahwa data berdistribusi normal. Oleh karena itu dapat dikatakan sebelum diberi perlakuan di kelas tersebut mendapatkan hasil nilai rata-rata di bawah KKM, setelah diberi perlakuan yaitu dengan penerapan metode jarimatika dalam proses pembelajaran matematika 5 kali pertemuan perolehan nilai postest siswa meningkat dari sebelumnya.

Peneliti melakukan pembelajaran yang mengacu pada silabus dengan materi bilangan bulat positif . Dimana patokan keberhasilan siswa apabila telah mencapai nilai KKM. Alokasi waktu saat melaksanakan penelitian sama seperti proses pembelajaran pada umumnya dengan 8 kali pertemuan. Di pertemuan pertama dan kedua dilakukan pretest 4 kali, pertemuan ketiga sampai pertemuan ke enam dilakukan treatment melalui metode jarimatika dengan materi bilangan bulat positif berhitung perkalian, dan pertemuan ke tujuh dan pertemuan dilakukan postest 4 kali.

Pada awal pertemuan sebelum memulai pelajaran siswa diberikan pretest. Pretest merupakan tes yang diberikan pada awal pertemuan sebelum diberi perlakuan apapun. Setelah diberikan pretest diperoleh nilai rata-rata sebesar 66 sedangkan nilai rata-rata hasil posttest sebesar 81 . Pada tahap selanjutnya dilakukan uji normalitas untuk mengetahui data tersebut yang telah diperoleh berdistribusi normal atau tidak. Syarat sebuah data yaitu harus berdistribusi normal, dari hasil uji normalitas menunjukkan bahwa data tersebut berdistribusi normal. Hal ini ditunjukkan oleh hasil signifikansi pada saat pretest dan posttest yakni 0,200 dan 0,200 yang menyakatakan apabila nilai sig. $>0,05$ maka data tersebut berdistribusi normal.

Pada pertemuan 3 sampai 5 diberikan perlakuan berupa metode jarimatika pada masing-masing siswa di kelas tersebut dan di pertemuan ke enam dam ke tujuh diberi postest dengan soal yang setara dengan pretest untuk mengetahui perbedaan hasil tes antara sebelum dan sesudah diberikannya perlakuan. Berdasarkan hasil posttest pada kelas IVA MIN Malawele Aimas Kabupaten Sorong didapatkan nilai rata-rata sebesar 81 dengan perolehan nilai tertinggi adalah 100 dan nilai terendah adalah 60. Kemudian data posttest selanjutnya digunakan sebagai uji hipotesis untuk membuktikan kebenaran dari hipotesis yang telah diajukan yaitu ada atau tidaknya peningkatan hasil belajar. Uji hipotesis yang digunakan dalam penelitian ini yaitu uji one sample t test.

Hasil uji one sample t test menunjukkan bahwa adanya perbedaan yang signifikan terhadap peningkatan hasil belajar sebelum dan setelah diberi perlakuan dengan penerapan 
metode jarimatika pada kelas IV MIN Malawele. Hal ini dapat diketahui dengan perolehan data hasil uji yakni signifikansi pada postest sebesar $0,000<0,05$ yang menyatakan bahwa adanya peningkatan sesudah diterapkannya metode jarimatika. Hasil analisis tersebut membuktikan bahwa metode inkuiri dapat mempengaruhi tercapainya hasil belajar siswa.

\section{Pengaruh Metode jarimatika Terhadap kemampuan berhitung Siswa}

Penerapan metode jarimatika dengan tujuan untuk melihat pengaruh metode tersebut terhadap kemampuan berhitung siswa kelas IV SD/MI ternyata sangat berpengaruh karena metode ini merupakan salah satu metode pembelajaran matematika terbaru yang belum pernah diterapkan oleh guru sebelumnya dan memberikan daya minat siswa terhadap pembelajaran matematika.

Metode jarimatika adalah metode berhitung dengan menggunakan sepuluh jari yang memungkinkan siswa agar aktif dalam proses pembelajaran matematika. sesuai dengan kemampuannya masing-masing untuk menemukan pemecahan masalah yang telah diberikan. Peneliti dengan metode yang digunakan membuat kondisi belajar di kelas menjadi lebih hidup agar siswa tidak cepat bosan saat mengikuti pelajaran. Setelah diterapkannya metode tersebut diketahui dari keaktifan siswa dalam belajar meningkat karena hal ini dapat terlihat dari antusias siswa dalam mengikuti proses pembelajaran matematika.Berdasarkan aktivitas pembelajaran dengan diterapkannya metode jarimatika mengalami peningkatan hasil belajar sebelum dan sesudah diberi perlakuan.

Dari hasil pengolahan data deskriptif statistik diperoleh nilai tertinggi saat posttest yaitu 100 dan nilai terendah 60 . Dengan rata-rata postestnya yaitu 81,72 standar deviasinya 10,922 dan variannya 119,293. Hal ini dapat dikatakan perubahan kemampuan berhitung pada siswa IVA di MIN Malawele Aimas terjadi karena adanya pengaruh dari metode jarimatika yang diterapkan oleh peneliti.

Berdasarkan hasil penelitian yang telah dilaksanakan diketahui bahwa proses pembelajaran berlangsung dengan baik, mulai dari awal penelitian kegiatan inti hingga akhir pelajaran dinyatakan baik dan sesuai prosedur yang telah dirancang dalam RPP. Namun ada faktor selain pengaruh penerapan metode jarimatika yaitu kesungguhan dan motivasi siswa dalam mengikuti pelajaran. Berdasarkan pemaparan tersebut, maka dapat disimpulkan bahwa metode jarimatika berpengaruh positif terhadap kemampuan berhitung atau hasil belajar siswa mata pelajaran matematika materi "bilangan bulat postif pada siswa kelas IVA MIN Malawele Aimas Kabupaten Sorong tahun ajaran 2017/2018.

\section{Simpulan}

Dari hasil penelitian dan pembahasan di atas Penulis mengambil kesimpulan bahwa ada pengaruh metode jarimatika terhadap kemampuan berhitung bilangan bulat positif di kelas IVA MIN Malawele dengan berdasarkan perhitungan statisktik deskriptif rata-rata pretest dan rata-rata postest dengan jumlah 21 siswa maka: rata-rata pretest diperoleh nilai minimum 23,75 , nilai maksimum 96,25 , nilai rata-rata 66,07 , dan nilai simpangan baku 18,688 , sedangkan rata-rata postest diperoleh nilai minimum 61,25, nilai maksimum 97,50, nilai rata-rata 81,72 dan nilai simpangan baku 10,922

Penelitian kuasi eksperimen bentuk time series design ini dinyatakan berhasil dengan melihat perbedaan hasil rata-rata pretest dengan postest dari 66,07 menjadi 81,72. Hal ini menunjukkan bahwa adanya pengaruh metode jarimatika terhadap kemampuan berhitung bilangan bulat positif siswa kelas IVA MIN Malawele Kabupaten Sorong. 


\section{Daftar Rujukan}

Abbas, Shaleh. 2006. Pembelajaran Bahasa Indonesia yang Efektif di Sekolah Dasar. Jakarta: Departemen Pendidikan Nasional.

Arikunto, Suharsini. 2006. Prosedur Penelitian: Suatu Pendekatan Dan Praktek Jakarta: Rineka Cipta.

Depdiknas. 2007. Pedoman Pembelajaran Berhitung Permulaan di TK. Jakarta: Depdiknas.

Fatkhurohmah. 2010. Peningkatan Kemampuan berhitung bilangan bulat melalui model pembelajaran Kooperatif (NHT) Pada siswa kelas V SD Muhammadiyah Wonorego

Polokarto Suloharjo Tahun Pelajaran 2009/2010. Universitas Sebelas Maret Surakarta.

Gunanto, dan Dhesy Adhalia. 2016. Matematika Untuk SD/MI Kelas IV. Jakarta: Erlangga. Ismawati, Esti. 2011. Cet. 2. Perencanaan Pengajaran Bahasa. Surakarta: Yuma Pustaka. Kadio dan Agus Suryana. 2009. Cet 4. Bermain Dengan Matematika. Jakarta: Lazuardi.

Lestari, Karunia Eka dan Mokhammad Ridwan Yudhanegara. 2015. Cet. 1. Penelitian Pendidikan: Matematika. Karawang: Refika Aditama.

Marini, Arita dan Iskandar Agung. 2011. Cet.1. Bahan Ajar Aritmatika Untuk PGSD. Jakarta: Bestari.

Mayasari, Erna. 2002. Cerdas Jarimatika. Bandung: Lingkar Media.

Mayasari, Erna. 2002. Cet. 1. Cerdas JariMatika. Bandung: Lingkar Media.

Nggermanto, Agus. 2016. Math Fun Learning: Jurus-Jurus Jago Matematika untuk SD/MI. Jakarta: Grasindo.

Runtukahu, J. Tombokan dan Selpius, Kandou. 2013. Cet. 3. Pembelajaran Matematika Dasar Bagi Anak Berkesulitan Belajar. Yogyakarta: Ar-Ruz Media.

Seniati, Liche, Aries Yulianto dan Bernadette N. Setiadi. 2009. Cet. 3. Psikologi Eksperimen. Jakarta: PT. Indeks.

Spiegel, M.R. dan Kasir Iskandar. 1987. Matematika Dasar. Jakarta: Erlangga.

Subroto, Seno. 2010. Seri Basaha Indonesia, Semarang : Aneka Ilmu.

Sudijono, Anas 2008. Cet. 8. Pengantar Evaluasi Pendidikan. Jakarta: PT Raja Grafindo Persada.

Sudjana, Nana Dan Ibrahim, 2010. Cet. 4. Penelitian dan Penilaian Pendidikan, Bandung: Penerbit Sinar Baru Algesindo.

Hamalik, Oemar. 2011. Proses Belajar Mengajar. Jakarta: Bumi Aksara.

Sugiono. 2015. Metode Penelitian Pendidikan: Pendekatan Kuantitatif, Kualitatif, dan R \& D. Bandung: Alfabeta.

Suwanda. Desain Eksperimen. Cet. 1 2011. Bandung: Penerbit Alfabeta.

Tumianto, Didik dan Nurhasanah. 2007. Kamus Besar Bergambar Bahasa Indonesia. Jakarta: Bina Sarana Pustaka.

Zarkasyi, Wahyudin. 2015. Penelitian Pendidikan Matematika. Bandung: PT. Refika Aditama. 